Deneysel Araştırma / Experimental Research

doi: $10.5835 /$ jecm.omu.29.04.010

\title{
Penisilinle oluşturulan epilepside kolinerjik ve nitrerjik maddelerin diken amplitüdüne etkisi
}

The effects of cholinergic and nitrergic substances on spike amplitude in penicillin induced epilepsy

\author{
Abdullah Hilmi Marangoz*a, Mehmet Yıldırım \\ ${ }^{a}$ Ondokuz Mayıs Üniversitesi, Tıp Fakültesi, Nöroşirurji Anabilim Dalı, Samsun, Türkiye \\ ${ }^{b}$ Karadeniz Teknik Üniversitesi, Tıp Fakültesi, Fizyoloji Anabilim Dall, Trabzon, Türkiye
}

\begin{tabular}{|c|c|}
\hline MAKALE & IILERİ \\
\hline Makale geçı & \\
\hline Geliş tarihi & : 12 / 07 / 2012 \\
\hline Kabul tarihi & : 08 / 08 / 2012 \\
\hline * Yazışma A & \\
\hline Abdullah Hil & Marangoz \\
\hline Ondokuz Ma & s Üniversitesi Tıp Fakültes \\
\hline $\begin{array}{l}\text { Nöroşirurji A } \\
\text { Samsun }\end{array}$ & bilim Dalı, \\
\hline E-posta: abd & ah.marangoz@omu.edu.tr \\
\hline
\end{tabular}

\author{
Anahtar Kelimeler: \\ Asetilkolin \\ Nitrik oksit \\ ECoG \\ Deneysel epilepsi \\ Diken amplitüdü \\ Siçan
}

Keywords:

Acetylcholine

Nitric oxide

ECoG

Experimental epilepsy

Spike amplitude

Rat

\section{ÖZET}

Literatürde asetilkolinin (ACh) ve nitrik oksitin (NO) epilepsideki yeriyle ilgili çalışmalar vardır. Bununla birlikte herhangi bir epilepsi modelinde muskarinik kolinerjik sistem ile nitrerjik sistem arasındaki etkileşim bilinmemektedir. Sunulan çalışmanın amacı, penisilin modeli deneysel epilepside, nitrerjik sistem ile muskarinik kolinerjik sistemin etkileşimini araştırmaktır. Deneylerde ağırlıkları ortalama $220 \pm 35$ gram olan 70 tane Wistar cinsi erişkin erkek sıçan kullanıldı. Bu hayvanlar kontrol (200 IU/1 $\mu 1$ penisilin), sodyum nitropurisid (SNP) $(50 \mu \mathrm{g} / 5 \mu \mathrm{l}), \mathrm{N} \omega$-nitro-L-arjinin metil ester (L-NAME) (100 $\mu \mathrm{g} / 5 \mu \mathrm{l}), \mathrm{ACh}(250 \mu \mathrm{g} / 5 \mu \mathrm{l}$, i.c.), atropin (100 ng i.c.), atropin+SNP (100 ng atropin ve $10 \mathrm{dk}$ sonra $50 \mu \mathrm{g}$ SNP i.c.), atropin+L-NAME (100 ng atropin sülfat ve $100 \mu \mathrm{g} / 5 \mu \mathrm{l}$ L-NAME i.c.), L-NAME+ACh $(100 \mu \mathrm{g} / 5 \mu \mathrm{l} \mathrm{L-NAME} \mathrm{ve} 10 \mathrm{dk}$ sonra $250 \mu \mathrm{g} / 5 \mu \mathrm{l} \mathrm{ACh}$ i.c.), ACh $+\mathrm{SNP}(250 \mu \mathrm{g} / 5 \mu \mathrm{l} \mathrm{ACh}$ ve $50 \mu \mathrm{g}$ SNP i.c. $)$ ve Atropin+ACh gruplarına ayrıldı. Çalışmamızın sonuçlarına göre intrakortikal penisilinden (200 IU/1 mikro litre) 2-5 dakika sonra ECoG'de epileptiform aktivite başladı. Asetilkolin ile SNP birlikte verildiğinde, 10. dakikadan itibaren deneylerin sonuna kadar penisilinin oluşturduğu epileptiform aktivite ve diken yükseklikleri, istatistik açıdan çok önemli ölçüde baskılandı. Muskarinik kolinerjik ve nitrerjik sistemlerle ilgili diğer uygulamalar ve diğer maddeler diken yüksekliklerini istatistiksel açıdan önemli sayılabilecek ölçüde etkilememiştir. Sonuç olarak deney şartlarında, asetilkolin tek başına uygulandığında penisilinin olușturduğu epileptiform aktiviteyi şiddetlendirmekte; fakat bir NO verici olan SNP ile birlikte verilince antikonvülzan etki artmakta ve diken yükseklikleri azalmaktadır.

J. Exp. Clin. Med., 2012; 29:304-310

\section{ABSTRACT}

The role of acetylcholine ( $\mathrm{ACh}$ ) and nitric oxide (NO) in epilepsy is already known. There is no study on the interactions between cholinergic and nitrergic systems in an epilepsy model. The aim of this study was to investigate the interaction between muscarinic cholinergic system and nitrergic system in the experimental model of penicillin epilepsy. Seventy adult male Wistar rats weighing $220 \pm 35 \mathrm{~g}$ were used in the experiments. The experimental groups consist of control $(200 \mathrm{UI} / 1 \mu \mathrm{l}$ penicillin), SNP $(50 \mu \mathrm{g} / 5 \mu \mathrm{l}), \mathrm{N}$ $\omega$-nitro-L-arginine methyl ester (L-NAME) $(100 \mu \mathrm{g} / 5 \mu \mathrm{l})$, ACh $(250 \mu \mathrm{g} / 5 \mu \mathrm{l})$, atropin $(100 \mathrm{ng}$,), atropin+SNP (100 ng atropine and $10 \mathrm{~min}$ later $50 \mu \mathrm{g}$ SNP), atropin +L-NAME (100 ng atropine sulphate and $100 \mu \mathrm{g} / 5 \mu \mathrm{L}$-NAME,), L-NAME+ACh $(100 \mu \mathrm{g} / 5 \mu \mathrm{l}$ L-NAME and $10 \mathrm{~min}$ later $250 \mu \mathrm{g} / 5 \mu \mathrm{l} \mathrm{ACh}), \mathrm{ACh}+\mathrm{SNP}(250 \mu \mathrm{g} / 5 \mu \mathrm{l} \mathrm{ACh}$ and $50 \mu \mathrm{g}$ SNP) and Atropin+ACh groups. According to the this study, epileptiform activity started within 2-5 min following the intracortical injection of penicillin (200 UI/1 $\mu \mathrm{l})$. When ACh and SNP were administered together, penicillin induced epileptiform activity and spike amplitudes were significantly suppressed from the 10th min onwards. Amplitudes of the spikes induced by penicillin were significantly reduced in $\mathrm{ACh}+\mathrm{SNP}$ group while the other compounds related to muscarinic cholinergic and nitrergic systems did not affect it. It can be concluded that acetylcholine increases the epileptiform activity induced by penicillin when administered alone while the anticonvulsant effect is increased when it is administered together with NO donor SNP.

J. Exp. Clin. Med., 2012; 29:304-310 


\section{Giriş}

Antibiyotiklerin epileptiform aktivite oluşturduklarını gösteren çok sayıda in vivo ve in vitro çalışmalar vardır (Gutnick ve ark., 1976; Fisher, 1989; Grondahl ve Langmoen, 1993; Lösher ve Schmidt, 1994; Marangoz, 1997). Antibiyotikler içinde, çözünürlüğü daha yüksek olduğundan penisilinin sodyum ve potasyum tuzları tercih edilir. Deneysel epilepsinin oldukça kullanışlı ve ucuz modellerinden birisi de penisilin modelidir. Penisilinin konvulsan özelliği 1945 yılından beri bilinmektedir (Walker ve Johnson, 1945).

1980 yılında asetilkolinin, izole damarlarda genişlemeye sebep olduğu, ancak damar endoteli çıkarıldığında bu etkinin görülmediği bulunmuştur (Furchgott ve Zawadzki, 1980). Daha sonra asetilkolinin uyardığ 1 endotel hücrelerinden endotel kaynaklı gevşetici faktör (EDRF) denen bir maddenin salgılanarak damarları genişlettiği saptandı. 1987 yılında bu damar genişletici faktörün nitrik oksit (NO, nitrojen monoksit) veya ona benzeyen bir madde olduğu anlaşıldı (Ignarro ve ark., 1987; Palmer ve ark., 1987).

Nitrik oksitin hem prokonvulsan (Mollace ve ark., 1991) hem de antikonvulsan (Marangoz ve ark., 1994; Marangoz , 1996; Marangoz ve Bağırıcı, 2001) olduğunu iddia eden çok sayıda çalışma bulunmaktadır. Siçanda intraserebroventriküler (i.c.v.) N-metil D-aspartat (NMDA)'1n subkonvulsiv dozundan (0,5 mikrogram) bir dakika önce lateral ventriküle verilen NO'nun ön maddesi L-arjinin, elektrokortikogramda (ECoG) yüksek voltajlı senkronize deşarjlara yol açmış; L-arjinin ile NOS inhibitörü N-nitro L-arjinin birlikte uygulandığında epileptiform aktivite önlenmiştir (Mollace ve ark., 1991). NMDA reseptörünün uyarılmasından önce NO üretiminin baskılanması epileptiform aktiviteyi azaltmış, epileptik aktivite başladıktan sonra NO üretiminin engellenmesi ise etkisiz kalmıştır (De Sarro ve ark., 1991). Kainik asit (10 $\mathrm{mg} / \mathrm{kg}$, s.c) verilen sıçan beyninde NO üretimi araştırılmış ve üretimin temporal korteks ile amigdalada 6 kat, korteksin diğer kısımlarında ise 12 kat artış gösterdiği; önceden özel bir NOS inhibitörü olan 7-nitroindazol (7-NI) verildiğinde, kainik asitin oluşturduğu NO üretimi ve epileptiform aktivitenin azaldığı bulunmuştur (Mülsch ve ark., 1994). Deneysel epilepside NO üretiminin arttığını gösteren başka çalışmalar da vardır (Marangoz, 1996; Kaputlu ve Uzbay, 1997; Gupta ve Dettbarn, 2003; Kato ve ark., 2005). Bu çalışmalarda NO’nun prokonvulsan olduğu ileri sürülmüştür.

Nitrerjik sistemin antikonvulsif olduğunu gösteren çalışma sayısı da oldukça fazladır (Buisson ve ark., 1993; Marangoz ve ark., 1994; Marangoz ve Bağırıc1, 2001; Canan, 2004; Ayyıld1z ve ark., 2007; Yang ve Cox, 2007; Hrnčić ve ark., 2010). Farede lateral ventriküle verilen NMDA'nın oluşturduğu epileptiform aktivite, NO sistemi baskılandığında artış göstermiş; NMDA ile birlikte L-arjinin veya cGMP verilmesi epileptik aktiviteyi azaltmıştır (Buisson ve ark., 1993). Deneysel epilepsinin kainik asit modeliyle yapılan çalışmalardan birçoğu, NO'nun antikovulsan olduğunu göstermiştir (Marangoz ve ark., 1994; Przegalinski ve ark., 1994; Bagetta ve ark., 1995; Maggio ve ark., 1995; Rigaud-Monnet ve ark., 1995). Anestezi altındaki sıçanda beyin korteksine verilen 400-500 ünite penisilinle oluşturulan epileptiform aktiviteyi, bir NO salıcı olan sodyum nitroprussit (SNP) önemli ölçüde baskılamış; Guanilat siklaz veya NO inhibitörü olan hemoglobin, SNP'nin antikonvulsif etkisini önlemiştir (Marangoz ve ark., 1994).

Asetilkolin reseptörleri nikotinik ve muskarinik diye iki büyük gruba ayrılır. Muskarinik grupta beş ayrı alt tip reseptör (M1-M5) olduğu bilinmektedir. M1, M3 ve M5 alt tiplerinin eksitatör sinaptik iletiye, M2 ve M4 alt tiplerinin ise inhibitör sinaptik iletiye aracılık ettikleri saptanmıştır (McKinney ve Coyle, 1991). Pilokarpinin yabani farelerde epileptik nöbet oluşturduğu fakat M1 reseptörünü ihtiva etmeyen farelerde nöbet oluşturmadığı bulunmuştur (Hamilton ve ark., 1997). Ayrıca M2-M5 reseptörlerinin bulunmaması pilokarpinin oluşturduğu epileptik nöbetleri etkilememiştir (Bymaster ve ark., 2003). Özetlenen bulgular, en azından bazı epileptik nöbetler ile M1 reseptörleri arsında ilişki olduğunu göstermektedir (Bymaster ve ark., 2003).

Asetilkolinin merkez sinir sisteminde eksitatör bir etki gösterdiği öteden beri bilinmektedir (Krnjevic ve ark., 1971; Echlin, 1974; Krnjevic, 2004). Kortikal piramidal hücrelerin bulunduğu ortama verilen ACh hücrelerin uyarılabilirliğini artırmıştır (McCormick ve Prince, 1985). Asetilkolin, muskarinik reseptörler üzerinden hipokampus piramidal nöronlarında saatlerce süren deşarja yol açmıştır (Bernardo ve Prince, 1982). Muskarinik asetilkolin reseptör sayısının, tutuşma modeli epilepsi (MacNamara, 1978) ve genetik modeli epilepside (Liles ve ark., 1986) azaldığı bulunmuştur. Ayrıca skopolamin, biperiden ve atropin gibi antikolinerjik maddelerin de epileptiform aktivite gösterdiklerine dair bulgular vardır (Tan ve ark., 1978).

Muskarinik kolinerjik sistemin epilepside rol oynadığ1nı gösteren çok sayıda çalışma bulunmaktadır. (Minvielle ve ark., 1953; Bagri ve ark., 1999; Eşkazan ve ark., 1999; Peterson ve ark., 2000; Potier ve Psarropoulou, 2001; Martin ve ark., 2005). Asetilkolinin ve kolinomimetik maddelerin, vasküler endotelde olduğu gibi, sıçan omurilik dilimlerinde de nitrik oksitin sentezini uyardıkları ve bir kısım etkilerini bu yolla gösterdikleri tespit edilmiştir (Xu ve ark., 1996). Otonom sinir sisteminde ve merkez sinir sistemiyle ilgili bazı olaylarda ACh ile NO arasındaki etkileşimi konu alan çalışmalar vardır. Ancak özellikle epilepside asetilkolin ile nitrik oksit arasındaki etkileşimin nasıl olduğu bilinmemektedir.

Yukarıda sıralanan bilgi ve bulgular deneysel epilepside nitrik oksit ile asetilkolin arasında bir etkileşimin olması gerektiğini düşündürmektedir. Sunulan çalışmanın amacı, henüz araştırılmamış olan bu konuyu penisilin modeli deneysel epilepside ele almak, diken frekansını ele alan çalışmamıza (Marangoz ve ark., 2012) katkı sağlamak, nitrerjik sistem ile muskarinik kolinerjik sistemin diken amplitüdüne olan etkisini tespit etmek, böylece epileptogenezin temel mekanizmalarını daha ileri ölçüde aydınlatmak ve nihayet klinik çalışmalara 1şık tutmaktır.

\section{Gereç ve yöntem}

\subsection{Deney hayvanları}

Deneylerde, ortalama $220 \pm 35$ gram ağırlığında 70 adet Wistar cinsi, erkek sıçan kullanıldı. Hayvanlar 10-12 haftalık oluncaya kadar, Ondokuz Mayıs Üniversitesi Tıp Fakültesi Tıbbi ve Cerrahi Araştırma Merkezi'nde doğal aydınlık- 
karanlık döngüsünde herhangi bir yem ve su kısıtlaması olmaksızın yetiştirildiler. Deneysel çalışmadan yaklaşık 10 gün önce Cerrahi Araştırma Merkezi'nden alınan hayvanlar, Fizyoloji Anabilim Dalı Araştırma Laboratuarı'nda benzer bakım koşullarında kontrol altında tutuldular. Deneysel araştırma standartlarına uymayan sıçanlar çalışma dışında bırakıldılar. Deneysel çalışma için Ondokuz Mayıs Üniversitesi Etik Kurulundan onay alınd.

\subsection{Kullanılan kimyasal maddeler ve uygulanış şekil-} leri

Penisilin G potasyum DEVA Holding A.Ş. (İstanbul) firmasından temin edildi. Deneylerde kullanılan diğer kimyasal maddeler Sigma-Aldrich Co. (St. Louis, MO, US)'dan temin edildi. Epileptiform aktiviteyi başlatmak için 200 ünite (IU) penisilin $1 \mu \mathrm{l}$ hacimde intrakortikal (i.c.) olarak uygulandi. Penisilin hayvanın sol somatomotor korteksine, Bregma'dan $3 \mathrm{~mm}$ lateteral, $2 \mathrm{~mm}$ posteriyor ve $2 \mathrm{~mm}$ ventral koordinatlara uygun şekilde Hamilton mikroenjektör kullanılarak verildi (şek. 1).

SNP, penisilin enjeksiyonu ile başlayan epileptiform aktiviteden yaklaşık $30 \mathrm{dk}$ sonra serum fizyolojikte çözülerek hazırlanmış olan SNP, hayvan başına $50 \mu \mathrm{g} / 5 \mu \mathrm{l}$ oranında i.c. olarak uygulandi. N $\omega$-nitro-L-arjinin metil ester (L-NAME) hidroklolorid arjinin analoğu olan L-NAME, NO üretimini engelleyen nonspesifik bir ajandır. Penisilin enjeksiyonu ile başlayan epileptiform aktiviteden yaklaşık $30 \mathrm{dk}$ sonra serum fizyolojikte çözülerek hazırlanmış olan L-NAME, hayvan başına $100 \mu \mathrm{g} / 5 \mu \mathrm{l}$ oranında i.c. olarak uygulandı.

Asetilkolin kuvaterner amonyum esteri olan ACh, penisilin enjeksiyonu ile başlayan epileptiform aktiviteden yaklaşık $30 \mathrm{dk}$ sonra, serum fizyolojikte çözülerek, hayvan başına 250 $\mu \mathrm{g} / 5 \mu \mathrm{l}$ oranında i.c. olarak uygulandi. Penisilin enjeksiyonu ile başlayan epileptiform aktiviteden yaklaşık $30 \mathrm{dk}$ sonra serum fizyolojikte çözülerek hazırlanmış olan atropin, hayvan başına $100 \mathrm{ng} / 1 \mu \mathrm{l}$ oranında i.c. olarak uygulandı.

\subsection{Deney grupları}

Penisilin modeli deneysel epilepside, kolinerjik ile nitrerjik sistemlerin etkileri ve etkileşimlerini araştırmak için öncelikle her iki sistemin etkisi ayrı ayrı incelendi. Daha sonra bu iki sisteme ait etken maddeler birlikte uyguland. Deney grupları aşağıdaki şekilde oluşturuldu.

1. Kontrol grubu: $(n=6) 200 \mathrm{IU} / 1 \mu \mathrm{l}$ penisilin i.c. verildikten $30 \mathrm{dk}$ sonra $5 \mu \mathrm{l}$ serum fizyolojik i.c. olarak uyguland1.

2. SNP grubu: $(n=6) 200 \mathrm{IU} / 1 \mu 1$ penisilin verildikten 30 dk sonra $50 \mu \mathrm{g}$ SNP serum fizyolojikte çözülerek $5 \mu \mathrm{l}$ hacimde i.c. olarak uygulandi.

3. L-NAME grubu: $(n=6) 200 \mathrm{IU} / 1 \mu 1$ penisilin verildikten $30 \mathrm{dk}$ sonra serum fizyolojikte çözülen $100 \mu \mathrm{g}$ L-NAME $5 \mu \mathrm{l}$ hacimde i.c. olarak uygulandi.

4. Asetilkolin grubu: $(n=6) 200 \mathrm{IU} / 1 \mu \mathrm{l}$ penisilin verildikten $30 \mathrm{dk}$ sonra serum fizyolojikte çözülen $250 \mu \mathrm{g}$ asetilkolin $5 \mu \mathrm{l}$ hacimde i.c. olarak uygulandi.

5. Atropin grubu: $(n=6) 200 \mathrm{IU} / 1 \mu 1$ penisilin verildikten $30 \mathrm{dk}$ sonra serum fizyolojik ile sulandirılan $100 \mathrm{ng} / \mu \mathrm{l}$ atropin sülfat i.c. olarak uygulandi.

6. Atropin+SNP grubu: $(n=6)$ Epileptiform aktivite oluşumundan yaklaşık $30 \mathrm{dk}$ sonra $100 \mathrm{ng}$ atropin sülfat ve $10 \mathrm{dk}$ sonra $50 \mu \mathrm{g}$ SNP i.c. olarak uyguland.
7. Atropin+L-NAME grubu: $(n=6)$ Epileptiform aktivite oluşumundan yaklaşık $30 \mathrm{dk}$ sonra $100 \mathrm{ng}$ atropin sülfat ve bir dakika içinde $100 \mu \mathrm{g} / 5 \mu \mathrm{l}$ L-NAME i.c. olarak uygulandi.

8. L-NAME+Asetilkolin grubu: $(n=6)$ Epileptiform aktivite oluşumundan yaklaşık $30 \mathrm{dk}$ sonra $100 \mu \mathrm{g} / 5 \mu \mathrm{l}$ L-NAME ve $10 \mathrm{dk}$ sonra $250 \mu \mathrm{g} / 5 \mu \mathrm{l}$ asetilkolin i.c. olarak uyguland1.

9. Asetilkolin+SNP grubu: $(n=6)$ Epileptiform aktivite oluşumundan yaklaşık $30 \mathrm{dk}$ sonra $250 \mu \mathrm{g} / 5 \mu \mathrm{l}$ asetilkolin ve bir dakika içinde $50 \mu \mathrm{g}$ SNP i.c. olarak uygulandi.

Yukarıdaki deney gruplarına ilave olarak, ikişer hayvana penisilin uygulanmaksızın yalnızca serum fizyolojik, SNP, L-NAME, asetilkolin veya atropin i.c. olarak uygulanarak, bu maddelerin bazal ECoG aktivitesi üzerindeki etkinlikleri incelendi.

\subsection{Cerrahi ișlem}

Operasyon öncesi 24 saat aç bırakılan sıçanlara, 1,2 g/kg üretan intraperitoneal (i.p.) yoldan verilerek anestezi uygulandı. Sıçanın başının üst kısmında iki kulak arasındaki tüyler temizlendikten sonra, hayvan operasyon masasına tespit edildi. Hayvanın kafa derisi rostro-kaudal doğrultuda, ortalama 3-4 cm uzunluğunda kemik dokuya kadar insize edilerek gerekli ekartasyon sağlandi. Sol somatomotor korteks üzerinde periost disseke edilerek, tur motoruyla kafatası kemiği dikkatlice kaldırıldı. Kemik dokuda meydana gelebilecek kanamalar bonewax (kemik mumu) ile engellendi. Sürtünmeden kaynaklanan ısınmayı önlemek maksadıyla tur uygulanan alana eşzamanlı serum fizyolojik enjeksiyonu uygulandı. Kafatası kemiği tamamen uzaklaştırıldı.

\subsection{Elektrofizyolojik kayıt işlemi}

Cerrahi operasyondan sonra siçanlar stereotaksik cihaza sabitlendi. Hayvanın kafa derisi 4 köşeden cerrahi ipliklerle tutturularak $37^{\circ} \mathrm{C}$ 'lik sıvı vazelin havuzu oluşturuldu. Böylece beyin ve diğer dokulardan sıvı kaybının engellenmesi, ısının muhafaza edilmesi ve sinyal artefaktların önlenmesi sağland1. Rektal proba bağlı bir homeotermik battaniye (Harvard Instrument, USA) ile hayvanların vücut 1sıları monitörize edilerek, $37^{\circ} \mathrm{C}$ 'de sabitlendi. Elektrofizyolojik kayı için 2 adet $\mathrm{Ag} / \mathrm{AgCl}$ top elektrot ve topraklama amaciyla 1 adet $\mathrm{Ag} / \mathrm{AgCl}$ klemp elektrot kullanıldı. Top elektrotlardan pozitif olanı bregmanın $2 \mathrm{~mm}$ önüne, negatif olanı ise bregmanın $5 \mathrm{~mm}$ arkasına, toprak elektrot ise kayıt jeli sürülerek sağ kulağa yerleştirildi. Elektrotlar yardımıyla alınan aktivite, bir amplifikatör (BioAmp ADInstruments, Australia) yard1miyla yükseltilerek, PowerLab 4/SP (ADInstruments, Australia) veri kayıt sistemine aktarıldı. PowerLab ile korteksten elde edilen biyolojik sinyaller (ECoG aktivitesi) Chart v5.1 (ADInstruments, Australia) yazılımı ile monitörize edilerek bilgisayara online kaydedildi. Veriler daha sonra offline olarak analiz edildi.

\subsection{Enjeksiyonlar}

Beyine yapılan tüm intrakortikal enjeksiyonlar, Bregma noktasindan $3 \mathrm{~mm}$ lateral, $2 \mathrm{~mm}$ posteriyor ve $2 \mathrm{~mm}$ ventrale bir Hamilton mikroenjektörü aracılığıyla gerçekleştirildi. İntrakortikal enjeksiyonlarda enjektör ucunun damarları zedelememesine dikkat edildi. Penisilin enjeksiyonu öncesinde tüm sıçanlardan yaklaşık $10 \mathrm{dk}$ bazal aktivite kaydı alındı. 


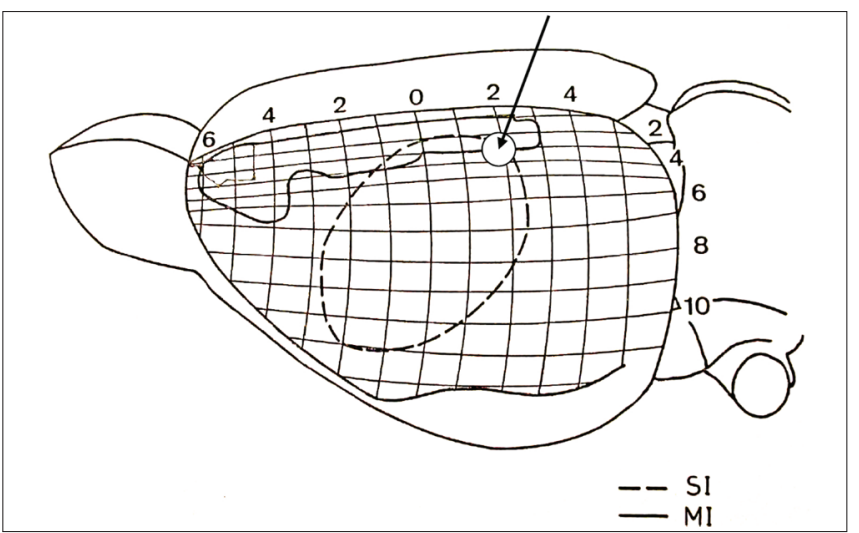

Şek. 1. Siçan beyninin sol hemisferinin üstten görünümü ve milimetrik koordinatları. Sıfır işaretli çizgi Bregmayı göstermektedir. Ok işareti enjeksiyon yerini belirtmektedir. S1 duyusal, M1 motor bölgeler (Marangoz, 2010).

\section{7. İstatistiksel analiz}

Elektrofizyolojik kayitlar Chart v5.1 (ADInstruments, Avustralya) yazılımı ve bu yazılımın makro özellikleri sayesinde birer dakikalık dilimlere ayrıldı. Her bir dakika başına düşen ortalama spike amplitüdleri otomatik olarak hesaplatıldı (Şek. 2a-2b). Bu işlemler her bir hayvan için tekrarlandı. Elektrofizyolojik kayıtlar sayısal verilere dönüştürüldükten sonra bu veriler, SPSS v12.0 yazılımı kullanılarak istatistiksel açıdan değerlendirildi.

Elde edilen verilerin normal dağılıma uygunluğu, OneSample Kolmogorov-Smirnov testi kullanılarak incelendi. Veriler normal dağılıma uyduğu için tek yönlü varyans analizi (ANOVA) kullanıldı. Varyans analizi sonucunda gruplar arasında istatistiksel açıdan anlamlı bir farkın olduğu görüldü. Grup varyansları heterojen olduğundan farkın nereden kaynaklandığını saptamak için Tamhane Post Hoc testi kullanıld1. Grafik ve metin içerisinde kullanılan deney gruplarına ait değerler ortalama \pm standart hata (SEM) olarak ifade edildi. Testlerden elde edilen sonuçlara göre p değeri 0,05 'in altında olan farklılıklar anlamlı kabul edildi (Şek. 1).

\section{Sonuçlar}

Tüm sıçanlarda, alınan bazal aktivite kayıtları arasında herhangi bir farklılığın bulunmadığı ve bazal aktivite kayıtlarında spontan spike oluşmadığg görüldü. Penisilin uygulanmaksızın sadece serum fizyolojik, SNP, L-NAME, asetilkolin ve atropinin intrakortikal enjeksiyonları sonucunda bazal ECoG aktivitesinde herhangi bir değişimin olmadığı ve spontan spike oluşmadı̆̆ saptandı.

İntrakortikal olarak penisilin $(200 \mathrm{IU} / 1 \mu \mathrm{l})$ uygulanan tüm hayvanlarda bilateral spike ve spike-dalga kompleksleri ile karakterize epileptiform ECoG aktivitesi oluştu. Epileptiform aktivite enjeksiyondan yaklaşık 2-5 dk sonra başladı. Bu aktivitede spike amplitüdü, enjeksiyondan yaklaşık $25 \mathrm{dk}$ sonra kararlı bir seviyeye ulaştı ve ortalama 4 saat devam etti.

Sunulan çalışmada ECoG aktivitesi penisilin enjeksiyonundan itibaren $90 \mathrm{dk}$ süreyle kaydedildi. Bunun ilk $30 \mathrm{da}-$ kikasında aktivite kararlı bir seviyeye ulaştı. Kalan 60 dk'lık dönemde nitrerjik ve kolinerjik sistemlere ait maddelerin enjeksiyonları yapılarak epileptiform aktivite üzerindeki etkileri incelendi.

\subsection{Penisilin verilmesinden sonraki ilk 30 dakikalık bölü- mün spike amplitüdü açısından karşılaştırılması}

Penisilin enjeksiyonundan sonra etkisi araştırılacak maddelerin verildikleri döneme kadar geçen yaklaşık 30 dakikalık dönemde, epileptik diken dalga amplitüdü açısından yapılan değerlendirmede gruplar arasında anlamlı bir farklılığın olmadığı görüldü $(\mathrm{p}>0,05)$. Tüm deney gruplarında etkisi araştırılacak madde enjeksiyonu öncesinde ortalama spike amplitüdünün $1190 \pm 184 \mu \mathrm{V}$ düzeyinde olduğu tespit edildi.

\subsection{Nitrik oksitin spike amplitüdüne etkisi}

SNP ve L-NAME enjeksiyonlarından $30 \mathrm{dk}$ ve sonra ortalama spike amplitüdü sirasiyla $1270 \pm 168 \mu \mathrm{V}, 1550 \pm 183$ $\mu \mathrm{V}$ olarak hesaplandi. SNP uygulandıktan kısa süre sonra ortalama spike amplitüdü kısmen azalarak deney sonuna kadar aynı düzeyde devam etmiştir. SNP grubundaki bu kısmi amplitüd azalmasının kontrol grubu ile karşılaştırıldığında istatiksel olarak anlamlı olmadığ tespit edildi $(p>0,05)$. L-NAME grubunda ise spike amplitüdünün yüzde değişiminin kontrol grubu değerleriyle yaklaşık paralel olduğu görüldü (Şek. 2a2b; Tablo 1).

\subsection{Asetilkolinin spike amplitüdüne etkisi}

Asetilkolin ve atropin enjeksiyonundan $30 \mathrm{dk}$ ve sonra ortalama spike amplitüdü sirasiyla $1060 \pm 55 \mu \mathrm{V}, 800 \pm 93 \mu \mathrm{V}$ olarak hesaplandi. Asetilkolin uygulanan grupta enjeksiyondan yaklaşık $5 \mathrm{dk}$ sonra spike amplitüdünde kısmi bir artış gözlense de, artışın anlamlı olmadığı ( $\mathrm{p}>0,05)$, elektrofizyolojik kaydın geri kalan bölümlerinde ise kontrol grubu düzeylerinde olduğu saptand1. Atropin uygulanan grupta ise 10 . dakikadan itibaren 25. dakikaya kadar anlamlı olmayan kısmi bir artışın olduğu fakat sonrasında kontrol grubu düzeylerine döndüğü tesbit edildi (Şek. 2a-2b; Tablo 1).

\subsection{Nitrik oksit ve asetilkolin etkileşiminin spike amp- litüdüne etkisi}

a) Muskarinik blokajda nitrik oksitin etkisi

Bu gruptaki hayvanlara muskarinik reseptör blokörü atropin (100 ng/5 $\mu \mathrm{l} / \mathrm{s} 1$ çan, i.c.) enjeksiyonundan $10 \mathrm{dk}$ sonra NO donörü SNP $(50 \mu \mathrm{g} / 5 \mu \mathrm{l} / \mathrm{s}$ ç̧an, i.c.) uygulandı. Atropin+SNP enjeksiyonundan $30 \mathrm{dk}$ sonra ortalama spike amplitüdü $616 \pm 208 \mu \mathrm{V}$ olarak hesapland. Atropin+SNP enjeksiyonu sonrasında spike amplitüdü kontrol grubu değerlerine göre azalmış olsa da standart hata değerinin (ve standart sapma) oldukça yüksek olmasından dolayı bu azalmadan kaynaklanan farkın istatiksel açıdan anlamlı olmadı̆̆ (Şek. 2a-2b; Tablo 1).

\section{b) Nitrik oksitin eksikliğinde asetilkolinin rolü}

L-NAME ve asetilkolin etkileşimini araştırmak için oluşturulan deney grubuna ilk önce L-NAME (100 $\mu \mathrm{g} / 5 \mu \mathrm{l} / \mathrm{s}$ sçan, i.c.) uyguland1. L-NAME+asetilkolin enjeksiyonundan $30 \mathrm{dk}$ sonra ortalama spike amplitüdü $1000 \pm 169 \mu \mathrm{V}$ olarak hesaplandı. Her iki maddenin enjeksiyonu sonrasında spike amplitüdünün kontrol grubu değerlerine yakın olduğu görüldü ( $>>0,05$; Şek. 2a-2b; Tablo 1).

\section{c) Asetilkolin ve nitrik oksitin birlikte etkileri}

Asetilkolin ve nitrik oksitin aynı ortamda birlikte artışlarından ortaya çıkacak etkileri görmek amacıyla oluşturulan deney grubuna penisilinden $30 \mathrm{dk}$ sonra asetilkolin $(250 \mu \mathrm{g} / 5$ 
$\mu \mathrm{l} / \mathrm{s}$ ıçan, i.c. $)$ ve SNP $(50 \mu \mathrm{g} / 5 \mu \mathrm{l} / \mathrm{s}$ ç̧an, i.c. $)$ birlikte ve aynı anda uyguland1. Asetilkolin+SNP enjeksiyonundan $30 \mathrm{dk}$ sonra ortalama spike amplitüdü $333 \pm 152 \mu \mathrm{V}$ olarak hesaplandı. Her iki madenin aynı anda uygulanmasının spike amplitüdünde ilk dakikalardan itibaren başlayan ve deney sonuna kadar süren bir azalmaya neden olduğu gözlendi. Asetilkolin+SNP grubunda 50. ve 60. dakikalar arasında kalan spike amplitüdü değerlerinin kontrol grubu değerlerine göre istatiksel açıdan anlamlı olacak şekilde azalmış olduğu tespit edildi $(\mathrm{p}<0,05$; Şek. 2a-2b; Tablo 1).

\section{d) Asetilkolin ve nitrik oksitin inhibisyonunun etkile-} ri

$\mathrm{Bu}$ deney grubunda muskarinik asetilkolin reseptör antagonisti atropin ve NOS inhibitörü L-NAME penisilin enjeksiyonundan $30 \mathrm{dk}$ sonra aynı anda uygulandılar. Atropin +L-NAME enjeksiyonundan $30 \mathrm{dk}$ sonra ortalama spike amplitüdü $680 \pm 144 \mu \mathrm{V}$ olarak hesapland1. Her iki sistemin aynı anda inhibe edilmesiyle spike amplitüdününde kontrol grubu değerlerine göre anlamlı bir farklılığın bulunmadığı saptand 1 ( $>$ >0,05; Şek. 2a-2b; Tablo 1).

\begin{tabular}{|c|c|c|c|c|}
\hline Zaman & \multirow{2}{*}{$15 \mathrm{dk}$} & \multirow{2}{*}{$30 \mathrm{dk}$} & \multirow{2}{*}{$45 \mathrm{dk}$} & \multirow{2}{*}{$60 \mathrm{dk}$} \\
\hline Gruplar & & & & \\
\hline Kontrol (Penisilin) & $1000 \pm 185$ & $900 \pm 178$ & $900 \pm 147$ & $900 \pm 166$ \\
\hline SNP & $1290 \pm 108$ & $1270 \pm 168$ & $1210 \pm 203$ & $1200 \pm 268$ \\
\hline L-NAME & $1550 \pm 170$ & $1550 \pm 183$ & $1620 \pm 168$ & $1480 \pm 181$ \\
\hline $\mathrm{ACh}$ & $940 \pm 55$ & $1060 \pm 55$ & $1080 \pm 48$ & $1060 \pm 33$ \\
\hline Atropin & $880 \pm 79$ & $800 \pm 93$ & $780 \pm 94$ & $720 \pm 104$ \\
\hline Atropin+SNP & $567 \pm 190$ & $616 \pm 208$ & $600 \pm 191$ & $600 \pm 191$ \\
\hline L-name $+\mathbf{A C h}$ & $1066 \pm 200$ & $1000 \pm 169$ & $1066 \pm 190$ & $783 \pm 54$ \\
\hline Atropin+L-Name & $780 \pm 168$ & $680 \pm 144$ & $540 \pm 187$ & $660 \pm 158$ \\
\hline $\mathrm{ACh}+\mathrm{SNP}$ & $333 \pm 154$ & $333 \pm 152$ & $233 \pm 147$ & $117 \pm 116$ \\
\hline
\end{tabular}

\section{Tartışma}

Atropinden sonra verilen SNP spike amplitüdünü önemli ölçüde etkilemedi. Bu bulgu literatür bilgileriyle uyumludur
(Yıldırım ve Marangoz, 2006; Marangoz, 2010; Yıldırım ve ark., 2011; Marangoz ve ark., 2012). Spesifik olmayan nitrik oksit sentaz (NOS) inhibitörü L-NAME'den $10 \mathrm{dk}$ sonra verilen asetilkolin diken frekansını anlamlı ölçüde etkilememiştir (Marangoz ve ark., 2012).

Asetilkolin ile SNP birlikte uygulandıklarında 10. dakikadan itibaren deneylerin sonuna kadar, penisilinin oluşturduğu epileptiform aktivitede diken amplitüdünü istatistik açıdan çok önemli ölçüde baskıladı. Benzer olarak asetilkolin ve SNP'nin birlikte uygulanmasının spike frekansını da baskıladığı gösterilmiştir (Marangoz, 2010; Marangoz ve ark., 2012).

Sunulan çalışmada, penisilinin oluşturduğu diken yüksekliklerinin sadece Asetilkolin+SNP grubunda etkilendiği ve istatistiksel açıdan anlamlı ölçüde azaldığı tespit edildi. Muskarinik kolinerjik ve nitrerjik sistemlerle ilgili diğer uygulamalar ve diğer maddeler diken yüksekliklerini istatistik açıdan önemli sayılabilecek ölçüde etkilemedi. Melatonin penisilinin oluşturduğu diken frekansını önemli ölçüde baskılarken, diken amplitüdünü etkilememiştir (Yıldırım ve Marangoz, 2006). Nitrik oksit ile adenosinin etkileşmesini konu edinen bir çalışmada, tek başına veya adenosin ile birlikte verilen SNP'nin diken amplitüdünü etkilemediği gösterilmiştir (Y1ldırım ve ark., 2011). Diğer taraftan intrakortikal SNP'nin penisilin modelinde diken amplitüdünü azalttığını gösteren çalışmalar da vardır (Marangoz ve ark., 1994). Söz konusu uyuşmazlık deney şartlarının farklı olmasıyla izah edilebilir. Tek başına prokonvulsif olan ACh'nın SNP ile birlikte verildiğinde, diken amplitüdünü hangi mekanizmayla baskıladığ henüz bilinmemektedir. ACh ve SNP'nin birlikte verilmesinin diken frekansını, SNP'nin tek başına olan etkisinden daha fazla baskıladığını gösteren Marangoz ve ark. (2012)'na göre bu konuda şu mekanizmalardan biri veya birkaçı birlikte devrede olmuş olabilir: 1) ACh nitrik oksit üretimini artırmış olabilir. 2) SNP kolinerjik maddelerin inhibitör muskarinik reseptörlere bağlanma ihtimalini artırıyor olabilir. 3) NO'nun etkisi redoks durumuna bağlıdır. ACh, NO'nun redoks durumunu etkileyerek onun baskılayıcı özelliğini öne çıkarıyor olabilir. 4) NO ACh yanında diğer nörotransmitterlerin sentezini de etkilemektedir. Asetilkolinle birlikte verilen SNP inhibitör transmitterlerin salgılanmasını daha fazla etkiliyor

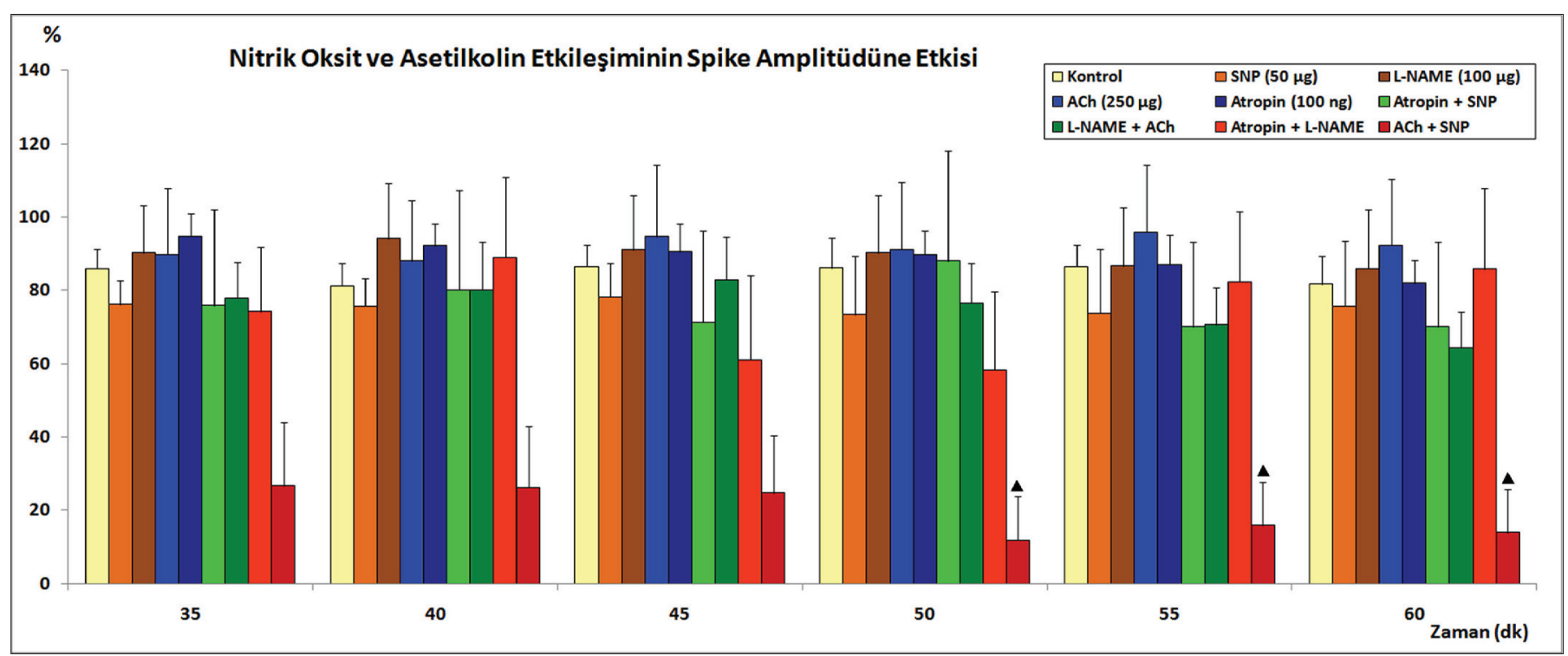

Şek. 2a. Asetilkolin, atropin, SNP, L-NAME ve bunların kombinasyonunun epileptiform aktivitede diken (spike) amplitüdüne etkisi (0-30. dakikalar). 


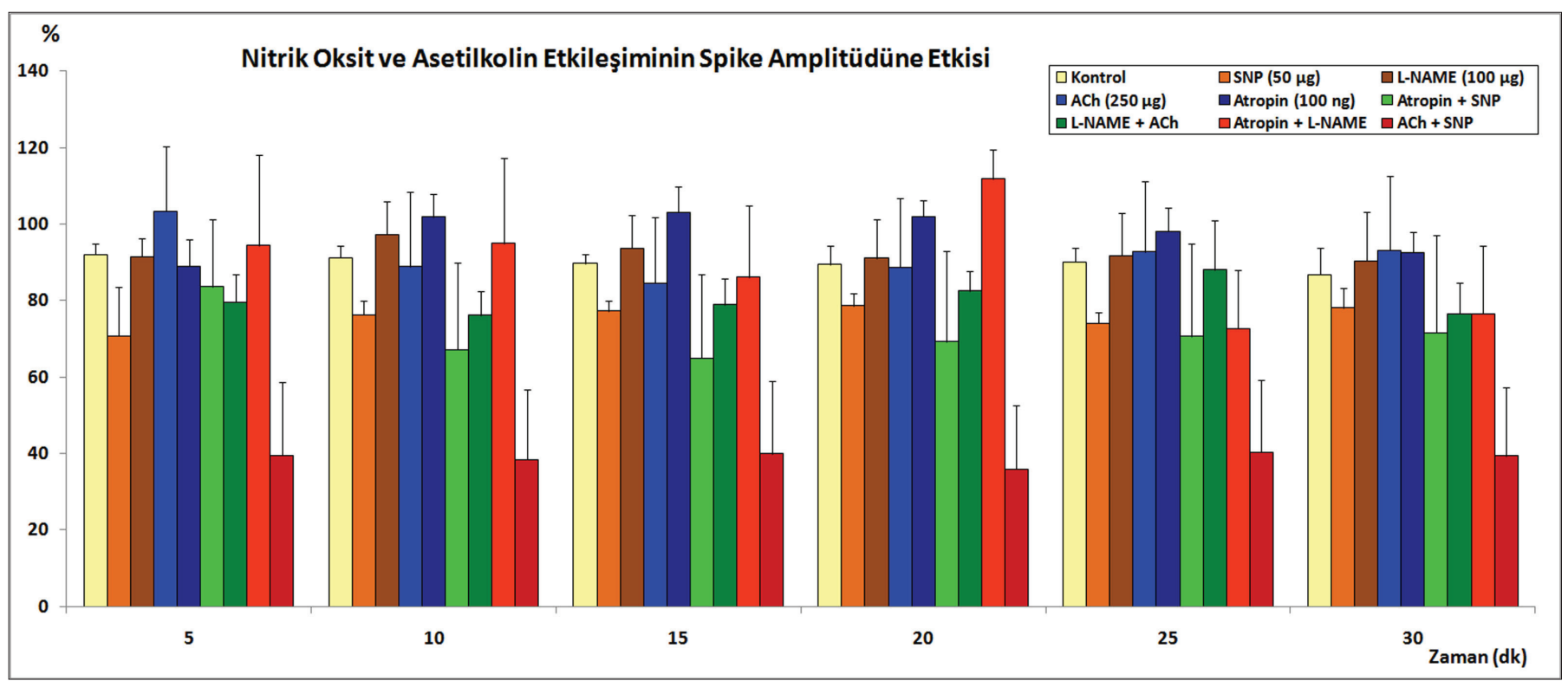

Şek. 2b. Asetilkolin, atropin, SNP, L-NAME ve bunların kombinasyonunun epileptiform aktivitede diken (spike) amplitüdüne etkisi (30-60. dakikalar).

olabilir. 5) Asetilkolin dolaylı yoldan, NO ise doğrudan beyin kan akımını artırarak hücre dışı potasyum miktarını azaltır. Sonuçta epileptiform aktivite ileri ölçüde baskılanabilir.

Özet olarak mevcut deney şartlarında elde edilen sonuçlara göre, dışarıdan verilen kolinerjik agonistler tek başına ol- duklarında epileptik aktiviteyi kolaylaştırırken, nitrerjik agonistle birlikte olduklarında, tersine olarak inhibitör sistemleri güçlendirmekte ve bu yolla epileptiform aktiviteyi ve diken amplitüdünü baskılamaktadırlar.

\section{KAYNAKLAR}

Bagetta, G., Iannone, M., Palma, E., Rodinò, P., Granato, T., Nisticò, G., 1995. Lack of involvement of nitric oxide in the mechanisms of seizures and hippocampal damage produced by kainate and ouabain in rats. Neurodegeneration. 4, 43-49.

Bagri, A., Di Scala, G., Sandner, G., 1999. Myoclonic and tonic seizures elicited by microinjection of cholinergic drugs into the inferior colliculus. Therapie. 54, 589-594.

Bernardo, L.S., Prince, D.A., 1982. Cholinergic excitation of mammalian hippocampal pyramidal cells. Brain Res. 249, $315-331$.

Buisson, A., Lakhmeche, N., Verrecchia, C., Plotkine, M., Boulu, R.G., 1993. Nitric oxide: An endogenous anticonvulsant substance. Neuroreport. 4, 444-446.

Bymaster, F. P., Carter, P. A., Yamada, M., Gomeza, J., Wess, J., Hamilton, S. E., Nathanson, N. M., McKinzie, D. L., Felder, C.C., 2003. Role of specific muscarinic receptor subtypes in cholinergic parasympathomimetic responses, in vivo phosphoinositide hydrolysis, and pilocarpineinduced seizure activity. Eur. J. Neurosci. 17, 1403-1410.

De Sarro, G., Di Paola, E.D., De Sarro, A., Vidal, M.J., 1991. Role of nitric oxide in the genesis of excitatory amino acid-induced seizures from the deep prepiriform cortex. Fund. Clin. Pharmacol. 5, 503-511.

Echlin, F., 1974. Time course of development of supersensitivity to topical ACh in partially isolated cortex. EEG and Clin. Neurophysiol. 18, 225-233.

Eşkazan, E., Aker, R., Onat, F., Köseoğlu, S., Gören, M.Z., Hasanoğlu, A., 1999. Effect of pirenzepine, a muscarinic M1 receptor antagonist, on amygdala kindling in rat. Epilepsy Res. 37, 133-140.

Fisher, R.S., 1989. Animal models of the epilepsies. Brain Res. Rev. 14, 245-278.

Furchgott, R.F., Zawadzki, J.V., 1980. Obligatory role of endothelial cells in the relaxation of arterial smooth muscle by acetylcholine. Nature. 288, 373-376.

Grondahl, T.O. and Langmoen, I.A., 1993. Epileptogenic effect of antibiotic drugs. J. Neurosurg. 78, 938-943.

Gupta, R.C., Dettbarn, W.D., 2003. Prevention of kainic acid seizures-induced changes in levels of nitric oxide and high-energy phosphates by 7-nitroindazole in rat brain regions. Brain Res. 981,184-192.

Gutnick, M.J., Van Duijn, H., Citri, N., 1976. Relative convulsant potencies of structural analogues of penicillin. Brain Res. 114, $139-143$.

Hamilton, S.E., Loose, M.D., Qi, M., Levey, A.I., Hille, B., McKnight, G.S., Idzerda, R.L., Nathanson, N.M., 1997. Disruption of the M1 receptor gene ablates muscarinic receptor-dependent $\mathrm{M}$ current regulation and seizure activity in mice. Proc. Natl. Acad. Sci. USA. 94, 1331113316.

Hrnčić, D., Rašić-Marković, A., Krstić, D., Macut, D., Djuric, D., Stanojlović, O., 2010. The role of nitric oxide in homocysteine thiolactoneinduced seizures in adult rats. Cell Mol. Neurobiol. 30, 219-231.

Ignarro, L.J., Buga, G.M., Wood, K.S., Byrns, R.E., Chaudhuri, G., 1987. Endothelium derived relaxing factor produced and released from artery and vein is nitric oxide. Proc. Natl. Acad. Sci. U.S.A. 84, 9265-9269

Kaputlu, I., Uzbay, T., 1997. L-NAME inhibits pentylenetetrazole and strychnine-induced seizures in mice. Brain Res. 753, 98-101.

Kato, N., Sato, S., Yokoyama, H., Kayama, T., Yoshimura, T., 2005. Sequential changes of nitric oxide levels in the temporal lobes of kainic acid-treated mice following application of nitric oxide synthase inhibitors and phenobarbital. Epilepsy Res. 65, 81-91.

Krnjevic, K., Pumain, B., Renaud L., 1971. The mechanism of excitation by ACh in the cerebral cortex. J. Physiol. 215, $247-268$.

Krnjevic, K., 2004. Synaptic mechanisms modulated by acetylcholine in cerebral cortex. Prog. Brain Res. 145, 81-93. 
Liles, W.C., Taylor, S., Finnel, R., Lai, H., Nathanson, N.M. 1986. Decreased muscarinic acetylcholine receptor number in the central nervous system of the tottering Mouse. J. Neurochem. 46, 977-982.

Lösher, W., Schmidt, D., 1994. Strategies in antiepileptic drug development: Is rational drug design superior to random screening and structural variation? Epilepsy Res. 17, 95-134.

MacNamara, J.O., 1978. Muscarinic cholinergic receptors participate in the kindling model of epilepsy. Brain Res. 154,415-420

Maggio, R., Fumagalli, F., Donati, E., Barbier, P., Racagni, G., Corsini, G.U., Riva, M., 1995. Inhibition of nitric oxide synthase dramatically potentiates seizures induced by kainic acid and pilocarpine in rats. Brain Res. 679, 184-187.

Marangoz, A.H., 2010. Deneysel epilepside kolinerjik ve nitrerjik maddelerin etkileşimi. Doktora Tezi, Ondokuz Mayıs Üniversitesi, Sağlık Bilimleri Enstitüsü, Samsun

Marangoz, A.H., Y1ldırım, M., Ayy1ldı, M., Marangoz, C., 2012. The interactions of nitric oxide and acetylcholine on penicilin-induced epilepsy in rats. Neurochem. Res. 37, 1465-1474.

Marangoz, C., 1997. Deneysel epilepsi modelleri. O.M.Ü. Tıp Dergisi. 14, 147-186.

Marangoz, C., 1996. Nitrik oksit ve deneysel epilepsi. O.M.Ü. Tip Dergisi. 13, 165-183.

Marangoz, C., Ayyıldız, M., Ağar, E., 1994. Evidence that sodium nitroprusside possesses anticonvulsant effects mediated through nitric oxide. Neuroreport. 5, 2454-2456.

Marangoz, C., Bagirici, F., 2001. Effects of L-arginine on penicillin-induced epileptiform activity in rats. Jpn. J. Pharmacol. 86, $297-301$.

Martin, E.D., Cena, V., Pozo, M.A., 2005. Cholinergic modulation of status epilepticus in the rat barrel field region of primary somatosensory cortex. Exp. Neurol. 196, 120-125

McCormick, D.A., Prince, D.A., 1985. Two types of muscarinic response to acetylcholine in mammalian cortical neurons. Proc. Natl. Acad. Sci. U.S.A. 82, 6344-6348.

McKinney, M., Coyle, J.T., 1991. The Potential for muscarinic receptor subtype-specific pharmacoterapy for Alzheimer's disease. Mayo Clin. Proc. 66,1225-1237.

Minvielle, J., Cadilhac, J., Passouant, P., 1953. The effect of atropine in epileptics. Rev. Neurol. (Paris) 89, 430-433.

Mollace, V., Bagetta, G., Nistico, G., 1991. Evidence that L-arginine possesses proconvulsant effects mediated through nitric oxide. Neuroreport. 2, 269-272.

Mülsch, A., Busse, R., Mordvintcev, P.I., Vanin, A.F., Nielsen, E.O., Scheel-Krüger, J., Olesen, S.P., 1994. Nitric oxide promotesseizure activity in kainate-treated rats. Neuroreport. 5, 2325-2328.

Palmer, R.M., Ferrige, A.G., and Moncada, S., 1987. Nitric oxide release accounts for the biological activity of endothelium-derived relaxing factor. Nature. 327, 524-526.

Peterson, S.L., Armstrong, J.J., Walker, M.K., 2000. Focal microinjection of carbacholinto the periaqueductal gray induces seizures in the forebrain of the rat. Epilepsy Res. 42, 169-181.

Potier, S., Psarropoulou, C., 2001. Endogenous acetylcholine facilitates epileptogenesis in immature rat neocortex. Neurosci. Lett. 302, 25-28.

Przegalinski, E., Baran, L., Siwanowicz, J., 1994. The role of nitric oxide in the kainate-induced seizures in mice. Neurosci. Lett. 170, 74-76.

Rigaud-Monnet, A.S., Heron, A., Seylaz, J., Pinard, E., 1995. Effect of inhibiting NO synthesis on hippocampal extracellular glutamate concentration in seizures induced by kainic acid. Brain Res. 673, 297-303.

Tan. Ü., Şenyuva, F., Marangoz, C., 1978. Electrocorticographic effects of topically aplied scopolamine. Epilepsia. 19, $223-232$.

Walker, A.E., Johnson, H.C., 1945. Convulsive factor in commercial penicillin. Arch. Surg. 50, 69-73.

Xu, Z., Yong, C., Eisenach, J.C., 1996. Acetylcholine stimulates the release of nitric oxide from rat spinal cord. Anesthesiology. 85, $107-111$.

Yang, S., Cox, C., 2007. Modulation of inhibitory activity by nitric oxide in the thalamus. J. Nerophysiol. 97, 3386-3395.

Yildırım, M., Marangoz, C, 2006. Anticonvulsant effects of melatonin on penicillin-induced epileptiform activity in rats. Brain Research. 1099, 183-188.

Yıldırım , M., Marangoz, A.H., Ayyıldız, M., Ankaralı A., Marangoz., C., 2011. The interactions of nitric oxide and adenosine on penicillin induced epileptiform activity in rats. Acta. Neurobiol. Exp. 71, 208-219. 